\title{
Aplikasi Sistem Informasi Geografis (SIG) dan Penginderaan Jauh untuk Pemetaan Daerah Penangkapan Ikan Tuna Mata Besar di Selatan Jawa dan Bali
}

\author{
Kadek Bagus Padmaningrat ${ }^{\text {a*}}$, I Wayan Gede Astawa Karang a , Abd. Rahman As-

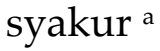 \\ a Program Studi Ilmu Kelautan, Fakultas Kelautan dan Perikanan, Universitas Udayana, Badung, Bali-Indonesia \\ * Penulis koresponden. Tel.: +62-815-576-578-2 \\ Alamat e-mail: bagus.padma@gmail.com
}

Diterima (received) 10 November 2016; disetujui (accepted) 6 Februari 2017; tersedia secara online (available online) 8 Februari 2017

\begin{abstract}
Bigeye tuna is the dominant species of tuna caught in the territorial waters of the Indian Ocean and a productive tropical species which accounts for more than $10 \%$ of the total catch in the whole world. Distribution of bigeye tuna can be predicted through optimum temperature associated with the presence of bigeye tuna and distribution of chlorophyll-a is associated with the presence of small pelagic fish. The distribution of sea surface temperature and chlorophyll-a can be detected through remote sensing systems. The purpose of this study was to determine the relationship between sea surface temperature and chlorophyll-a by the number of bigeye tuna catches in the waters south of Java and Bali, and mapped the area catching bigeye tuna in the waters south of Java and Bali. The method used is a second order polynomial regression analysis to determine the effect of sea surface temperature and chlorophyll-a by the number of bigeye tuna catches as well as correlation analysis to determine the relationship of sea surface temperature and chlorophyll-a by the number of bigeye tuna catches. Sea surface temperature and chlorophyll-a is related to the number of bigeye tuna catches. The results of the analysis showed a strong relationship between sea surface temperature and chlorophyll-a by the number of bigeye tuna catches. Bigeye tuna fishing grounds in the waters south of Java and Bali are in a position $12^{\circ} \mathrm{S}-15^{\circ} \mathrm{S}$ and $106^{\circ} \mathrm{E}-118^{\circ} \mathrm{E}$.
\end{abstract}

Keywords: Bigeye tuna; Sea surface temperature; Chlorophyll-a; Remote sensing

\begin{abstract}
Abstrak
Tuna mata besar merupakan jenis tuna yang dominan tertangkap di wilayah perairan Samudera Hindia dan merupakan spesies tropis produktif yang menyumbang lebih dari 10\% dari total tangkapan di seluruh dunia. Distribusi tuna mata besar dapat diprediksi melalui suhu optimum yang berhubungan dengan keberadaan tuna mata besar dan sebaran klorofil-a yang berhubungan dengan keberadaan ikan pelagis kecil. Sebaran suhu permukaan laut dan klorofil-a dapat diketahui melauli sistem penginderaan jauh. Tujuan dari penelitian ini adalah untuk mengetahui hubungan antara suhu permukaan laut dan klorofil-a dengan jumlah tangkapan tuna mata besar di perairan Selatan Jawa dan Bali serta memetakan daerah penangkapan tuna mata besar di perairan Selatan Jawa dan Bali. Metode yang digunakan adalah analisis regresi polinomial order dua untuk mengetahui pengaruh suhu permukaan laut dan klorofil-a dengan jumlah tangkapan tuna mata besar serta analisis korelasi untuk mengetahui hubungan suhu permukaan laut dan klorofil-a dengan jumlah tangkapan tuna mata besar. Suhu permukaan laut dan klorofil-a berhubungan dengan jumlah tangkapan tuna mata besar. Hasil analisis menunjukan hubungan yang kuat antara suhu permukaan laut dan klorofil-a dengan jumlah tangkapan tuna mata besar. Daerah penangkapan tuna mata besar di perairan Selatan Jawa dan Bali berada pada posisi $12^{\circ} \mathrm{LS}-15^{\circ} \mathrm{LS}$ dan $106^{\circ} \mathrm{BT}-118^{\circ} \mathrm{BT}$.
\end{abstract}

Kata Kunci: Tuna mata besar; Suhu permukaan laut; Klorofil-a; Penginderaan jauh 


\section{Pendahuluan}

Indonesia merupakan negara kepulauan dengan wilayah perairan yang luas dan berada diantara Samudera Hindia dan Samudera Pasifik. Luasnya perairan Indonesia menyebabkan tingginya potensi perikanan yang dimiliki dan terbagi dalam beberapa wilayah pengelolaann perikanan (Lasabuda, 2013). Salah satu wilayah perairan yang memiliki pontensi perikanan yang tinggi adalah perairan selatan Jawa dan Bali. Potensi perikanan yang lebih dominan di perairan selatan Jawa dan Bali adalah sektor perikanan tuna (Ekayana dkk., 2017; Syamsuddin et al., 2016; Swastana dkk., 2016; Lumban-Gaol et al., 2015; Sunoko and Huang, 2014). Tuna merupakan sumberdaya perikanan yang memiliki nilai ekonomis tinggi serta menjadi perikanan terbesar ketiga di Indonesia setelah udang dan ikan dasar (Tamarol and Wuaten, 2013). Tuna merupakan sumberdaya perikanan paling banyak menyumbang nilai ekspor mencapai USD 89,41 juta (KKP, 2015).

Tuna mata besar (Thunnus obesus) merupakan jenis tuna yang dominan tertangkap di wilayah perairan Samudera Hindia (ISSF, 2015; Arrizabalaga et al., 2015; Kaplan et al., 2014). Sejak tahun 1950 hingga 2013 hasil tangkapan tuna mata besar cukup berfluktuatif. Pada tahun 1950 sampai 2000 tangkapan tuna mata besar berkisar antara 6.589 hingga 136.030 ton. Pada tahun 1997-1999 merupakan puncak dari tangkapan tuna mata besar mencapai 150.000 hingga 160.000 ton. Selanjutnya pada tahun 2000-2013 hasil tangkapan tuna mata besar mengalami penurunan yang puncak tangkapan terendah terjadi pada tahun 2010 yang hanya mencapai 87.926 ton (IOTC, 2014). Hal ini berarti perlu diupayakan agar tangkapan tuna mata besar dapat ditingkatkan secara optimal.

Peningkatan secara optimal tangkapan tuna mata besar dapat dilakukan dengan menentukan daerah tangkapan tuna mata besar (Setiawati et al., 2015; Wibawa, 2011). Ketidakpastian daerah penangkapan menjadi kendala utama bagi para nelayan untuk meningkatkan efisiensi operasi penangkapan. Para nelayan umumnya masih menggunakan cara tradisional dengan menentukan lokasi banyaknya burung berterbangan di atas permukaan air yang menandakan terdapatnya kelompok ikan-ikan kecil yang merupakan makanan tuna mata besar.
Selain itu para nelayan lebih dominan menggunakan alat tangkap rawai tuna (longline) (Bahtiar dkk., 2013).

Prediksi penentuan daerah penangkapan ikan dapat dilakukan dengan analisis faktor oseanografi suhu permukan laut dan klorofil-a (Zainuddin et al., 2008). Pola sebaran suhu permukaan laut dapat digunakan untuk mengidentifikasi fenomena oseanografi seperti upwelling. Fenomena upwelling ini mempengaruhi kelimpahan, komposisi, dan distribusi fitoplankton karena adanya kandungan nitrat yang relatif tinggi (Barata dkk., 2014). Melimpahnya fitoplankton di suatu perairan mengindikasikan tingginya produktivitas perairan dan keberadaan ikan pelagis kecil yang merupakan makanan utama dari tuna mata besar (Semedi dan Safitri, 2014).

Pengukuran parameter oseanografi suhu permukaan laut dan klorofil-a di selatan Jawa dan Bali dapat dilakukan menggunakan sistem penginderaan jauh dengan citra satelit (Putra dkk., 2012). Penginderaan jauh merupakan ilmu dan seni untuk memperoleh informasi perairan secara menyeluruh (Semedi dan Hadiyanto, 2013). Dalam proses interpretasi data citra satelit, data diolah menggunakan Sistem Informasi Geografis (SIG) untuk menampilkan tampilan dalam bentuk peta. Penelitian ini dilakukan untuk mengetahui daerah penangkapan tuna mata besar serta hubungan suhu permukaan laut dan klorofil-a dengan jumlah tangkapan tuna mata besar di selatan Jawa dan Bali.

\section{Metode Penelitian}

\subsection{Lokasi Penelitian}

Lokasi penelitian berada di perairan selatan Jawa dan Bali pada kordinat $6-17^{\circ} \mathrm{LS}$ dan $106-118^{\circ} \mathrm{BT}$ yang merupakan bagian dari Wilayah Pengelolaan Perikanan Republik Indonesia (WPP-RI) 573 dapat dilihat pada Gambar 1. Analisis citra suhu permukaan laut dan klorofil-a dilakukan di Laboratorium Sistem Informasi Geografis (SIG) dan Penginderaan Jauh Fakultas Kelautan dan Perikanan Universitas Udayana.

\subsection{Alat dan Data Penelitian}

Alat dan data merupakan sarana penunjang pengambilan data ataupun sampel. Adapun alat 
dan data yang digunakan pada penelitian ini disajikan pada Tabel 1 dan Tabel 2.

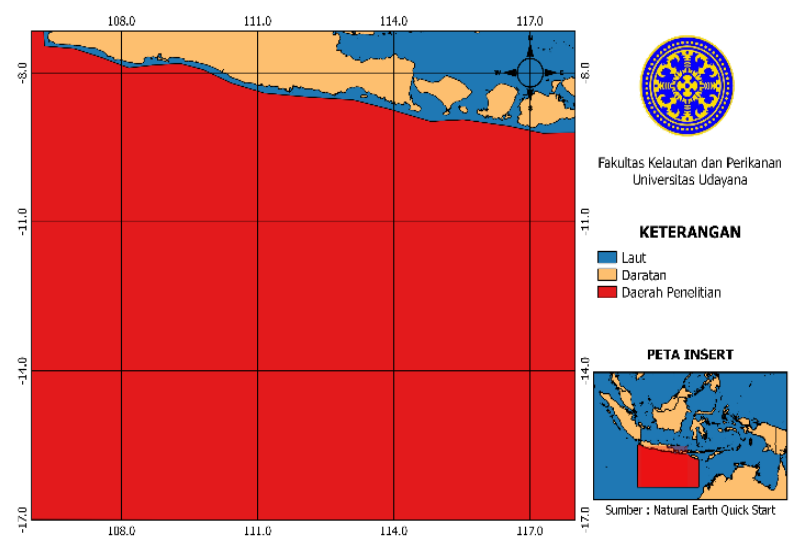

Gambar 1. Peta daerah penelitian.

Tabel 1.

Alat dalam penelitian

\begin{tabular}{|c|c|c|}
\hline No & Alat & Kegunaan \\
\hline 1 & $\begin{array}{l}\text { SeaDas } \\
7.3 .2\end{array}$ & $\begin{array}{l}\text { Mengolah citra suhu } \\
\text { permukaan laut dan klorofil- } \\
\text { a }\end{array}$ \\
\hline 2 & $\begin{array}{l}\text { Quantum } \\
\text { GIS } 2.8\end{array}$ & $\begin{array}{l}\text { Proses pembuatan peta } \\
\text { daerah penangkapan }\end{array}$ \\
\hline 3 & WinRAR & $\begin{array}{l}\text { Mengestrak citra suhu } \\
\text { permukaan laut dan klorofil- } \\
\text { a }\end{array}$ \\
\hline
\end{tabular}

Tabel 2.

Data dalam penelitian

\begin{tabular}{cl}
\hline No & \multicolumn{1}{c}{ Data } \\
\hline 1 & Data suhu permukaan laut dan klorofil-a \\
& dari citra satelit Aqua MODIS level 2 \\
& harian dengan resolusi 1x1 km² yang \\
& merupakan data harian dari tahun 2006- \\
& 2010. \\
2 & Data hasil tangkapan tuna mata besar di \\
& selatan Jawa dan Bali bulan Juni, Juli, dan \\
& Agustus tahun 2006-2010.
\end{tabular}

\subsection{Analisis Data}

\subsubsection{Analisis Deskriptif}

Data hasil tangkapan tuna mata besar, suhu permukaan laut, dan klorofil-a dianalisis secara deskriptif untuk membahas perubahan-perubahan yang terjadi di daerah penelitian selama Musim Timur tahun 2006-2010.

\subsubsection{Analisis Statistik}

\section{a. Data Tangkapan Tuna Mata Besar}

Data tangkapan tuna mata besar terdiri dari posisi geografis (lintang dan bujur) dari kegiatan penangkapan, hari operasional, dan jumlah tuna tertangkap per hari selama periode tersebut. Satuan data tangkap harian disebut sebagai jumlah tuna mata besar tertangkap. Frekuensi tangkapan dapat digunakan sebagai representasi dari kelimpahan ikan karena terbatasnya data in situ. Selanjutnya data tangkapan diklasifikasi untuk menyimpulkan jenis data tangkapan, untuk menentukan kisaran optimum dari parameter oseanografi, dan periode menangkap tertinggi (Andrade and Garcia, 1999; Zainuddin et al., 2008).

Data tangkapan dibagi kedalam tiga kategori yaitu pertama null catches, kedua positif catches, dan ketiga high catches (Andrade and Garcia, 1999). Dalam penelitian ini data tangkapan tuna mata besar dibagi dalam tiga kelompok yaitu pertama kelompok dimana hasil tangkapan sama dengan nol (null catches), kedua kelompok dengan hasil tangkapan 1-3 (positif catches), dan ketiga kelompok dengan hasil tangkapan lebih besar atau sama dengan 4 (high catches). Hasil tangkapan tinggi ditentukan berdasarkan batas bawah kuartil atas (Q3) yang diperoleh dari diperoleh dari 905 data tangkapan tuna mata besar dan 49 data validasi tangkapan tuna mata besar.

b. Pengaruh dan hubungan suhu permukaan laut dan klorofil-a terhadap jumlah tangkapan tuna mata besar

Analisis regresi polynomial order 2 digunakan untuk mengetahui pengaruh antara variabel bebas dengan variabel terikat. Analisis regresi polynomial order 2 menurut Bender et al. (2014) dijelaskan dalam persamaan 1 .

$Y=a_{0}+a_{1} x+a_{2} x^{2}$

dimana $Y$ adalah jumlah tangkapan, $a$ adalah kostanta, dan $x$ adalah parameter oseanografi (suhu permukaan laut dan klorofil-a).

Analisis korelasi dilakukan untuk mengetahui seberapa besar hubungan antara paremeter oseanografi (suhu permukaan laut dan klorofil-a) 
dengan jumlah tangkapan tuna mata besar. Analisis korelasi menurut Bender et al. (2014) dijelaskan dalam persamaan 2 .

$r=\frac{n \sum X_{i} Y-\left(\sum X_{i}\right)\left(\sum Y\right)}{\sqrt{\left\{n \sum X_{i}^{2}-\left(\sum X_{i}\right)^{2}\right\}\left\{n \sum Y_{i}^{2}-\left(\sum Y_{i}\right)^{2}\right\}}}$

dimana $r$ adalah nilai koefisien korelasi, $n$ adalah jumlah data tangkapan, $Y$ adalah jumlah tangkapan, dan $X$ adalah parameter oseanografi (suhu permukaan laut dan klorofil-a).

\subsubsection{Pemetaan Daerah Penangkapan Tuna Mata} Besar

Pemetaan daerah penangkapan tuna mata besar ini dilakukan dalam beberapa tahap, pertama menentukan suhu permukaan laut dan klorofil-a optimum untuk tangkapan pada kelompok positif catches dan high catches. Suhu permukaan laut dan klorofil-a optimum ditentukan berdasarkan standar deviasi dari data tangkapan tuna mata besar. Selanjutnya data di overlay secara terpisah berdasarkan parameternya. Data klorofil-a kelompok positif catch di overlay dengan data klorofil-a kelompok high catch dan data suhu permukaan laut kelompok positif catch di overlay dengan data suhu permukaan laut kelompok high catch. Setelah data di overlay sesuai dengan parameternya, selanjutnya dilakukan intersect untuk data kelompok positif catch dengan data kelompok high catch. Intersect ini dilakukan untuk memperoleh daerah tangkapan tuna mata besar di selatan Jawa dan Bali. Setelah diperoleh peta daerah tangkapan, selanjutnya mengoverlay data validasi yang sudah di klasifikasi ke dalam kelompok positif catch dan high catch.

\section{Hasil dan Pembahasan}

\subsection{Hasil}

\subsubsection{Sebaran Spasial Suhu Permukaan Laut}

Bulan Juni 2006 suhu permukaan laut di selatan Jawa dan Bali berkisar antara $25-28^{\circ} \mathrm{C}$. Bulan Juni 2007 suhu permukaan laut berkisar antara 25,7$28,8^{\circ} \mathrm{C}$. Bulan Juni 2008 suhu permukaan laut berkisar antara $25-28,2^{\circ} \mathrm{C}$. Bulan Juni 2009 nilai suhu permukaan laut berkisar antara 25,3-29,7॰C. Bulan Juni 2010 nilai suhu permukaan laut berkisar antara $26,5-30,2^{\circ} \mathrm{C}$. Sebaran suhu permukaan laut bulan Juni 2006-2010 dijelaskan pada Gambar 2.

Gambar 3 menampilkan sebaran spasial suhu permukaan laut pada bulan Juli tahun 2006 hingga 2010. Bulan Juli 2006 suhu permukaan laut berkisar antara $24-27^{\circ} \mathrm{C}$. Bulan Juli 2007 suhu

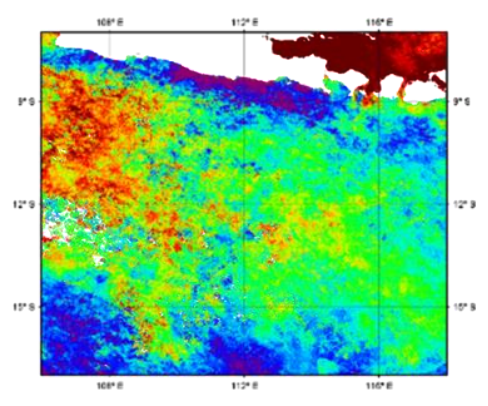

(a)

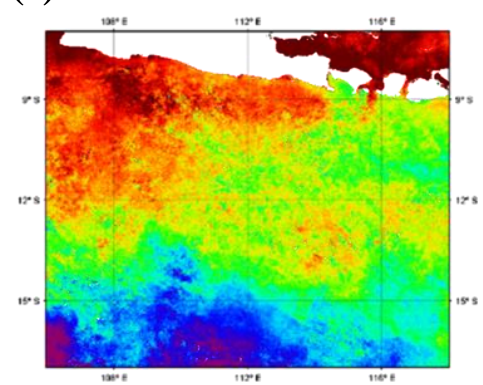

(d)

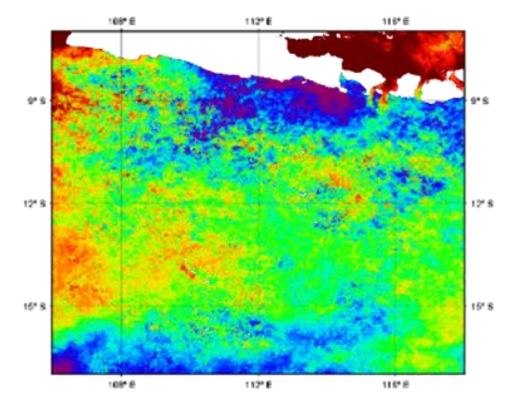

(b)

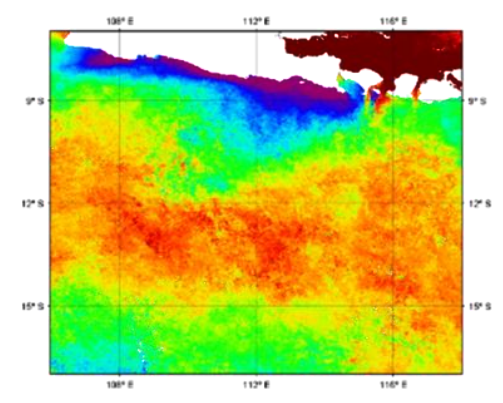

(c)

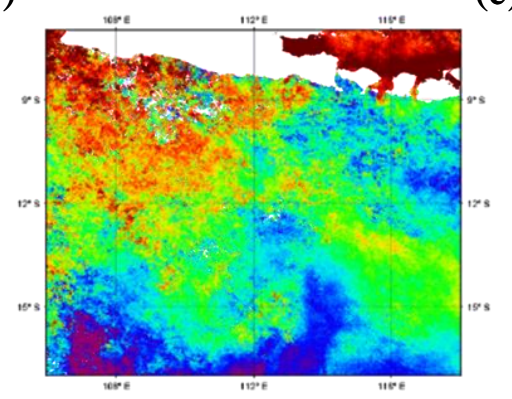

(e)

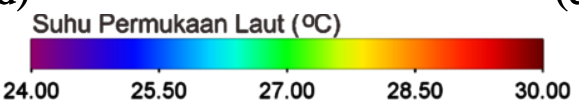

Gambar 2. Sebaran spasial suhu permukaan laut bulan Juni. (a) Tahun 2006, (b) Tahun 2007, (c) Tahun 2008,

(d) Tahun 2009, (e) Tahun 2010. 


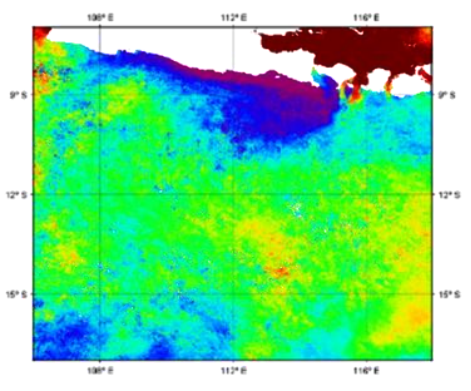

(a)

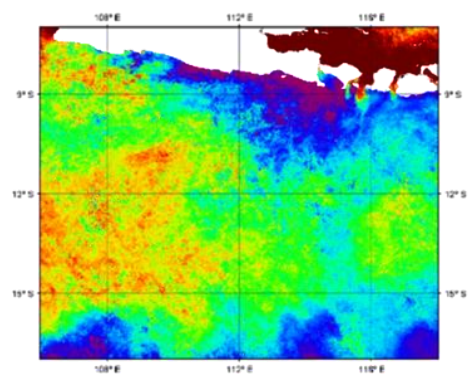

(b)

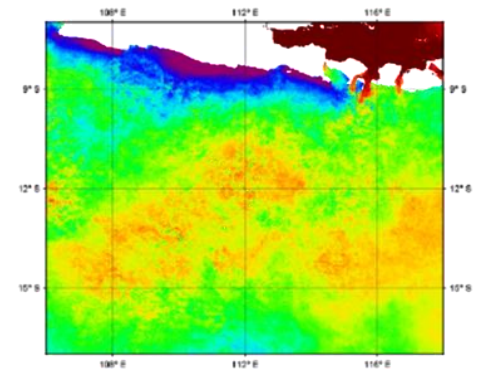

(c)

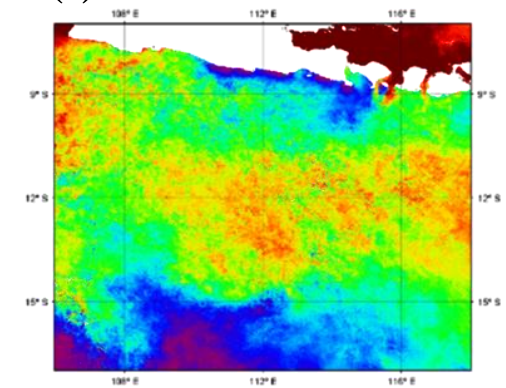

(d)

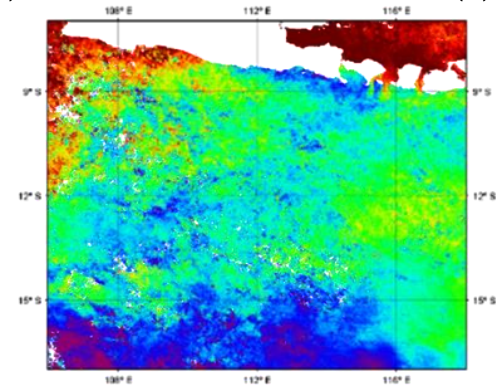

(e)

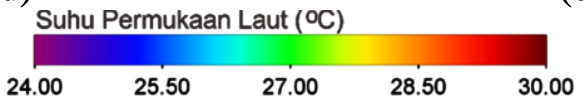

Gambar 3. Sebaran spasial suhu permukaan laut bulan Juli. (a) Tahun 2006, (b) Tahun 2007, (c) Tahun 2008, (d) Tahun 2009, (e) Tahun 2010.

permukaan laut berkisar antara $24,7-28^{\circ} \mathrm{C}$. Bulan Juli 2008 suhu permukaan laut berkisar antara 23$28^{\circ} \mathrm{C}$. Bulan Juli 2009 nilai suhu permukaan laut berkisar antara $25-28,7^{\circ} \mathrm{C}$. Bulan Juli 2010 nilai suhu permukaan laut berkisar antara $25-30^{\circ} \mathrm{C}$.
Gambar 4 menampilkan sebaran spasial suhu permukaan laut pada bulan Agustus tahun 2006 hingga 2010. Bulan Agustus 2006 suhu permukaan laut berkisar antara $23-26,7^{\circ} \mathrm{C}$. Bulan Agustus 2007 suhu permukaan laut berkisar antara $24-27,5^{\circ} \mathrm{C}$.

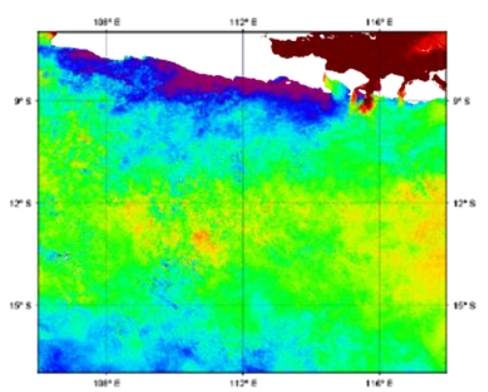

(a)

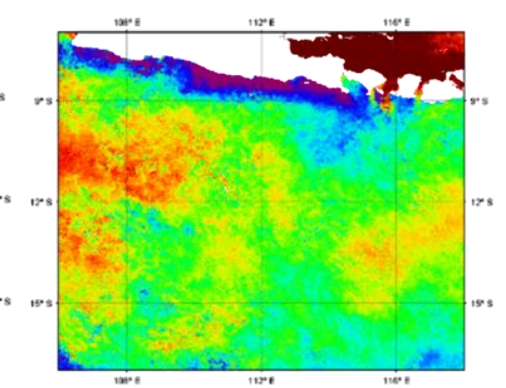

(b)

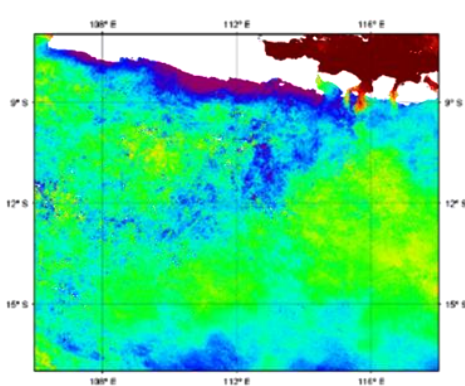

(c)

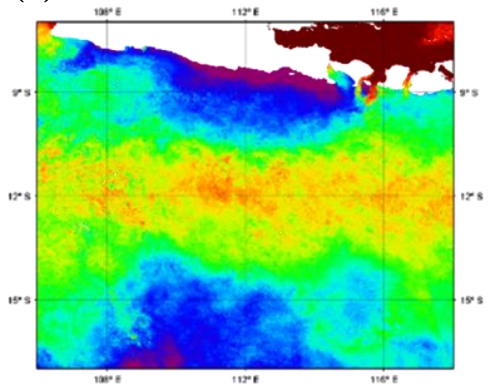

(d)

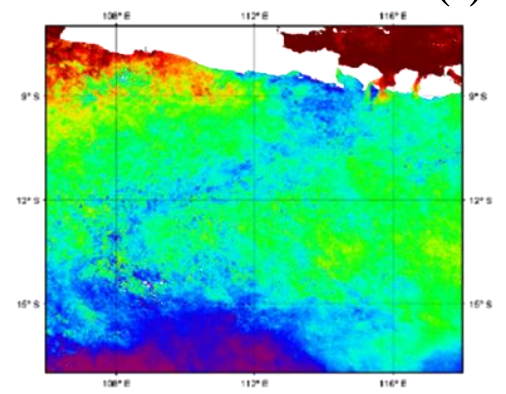

(e)

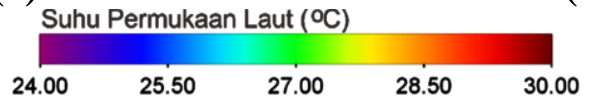

Gambar 4. Sebaran spasial suhu permukaan laut bulan Agustus. (a) Tahun 2006, (b) Tahun 2007, (c) Tahun 2008, (d) Tahun 2009, (e) Tahun 2010. 


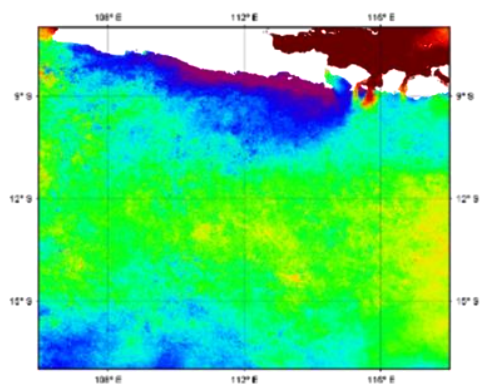

(a)

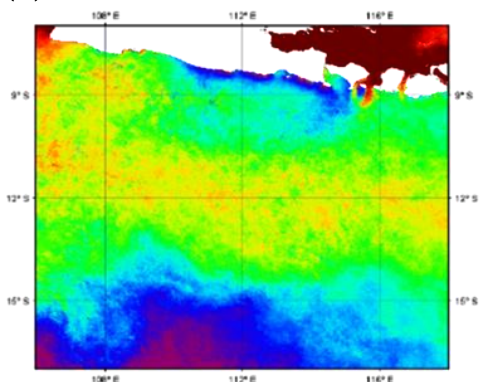

"Suhu Permúkaan Laut ( $\left.{ }^{\circ} \mathrm{C}\right)$

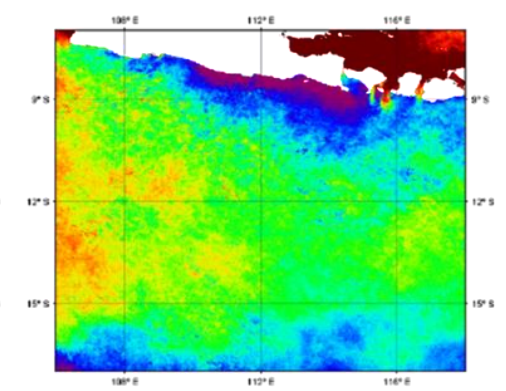

(b)

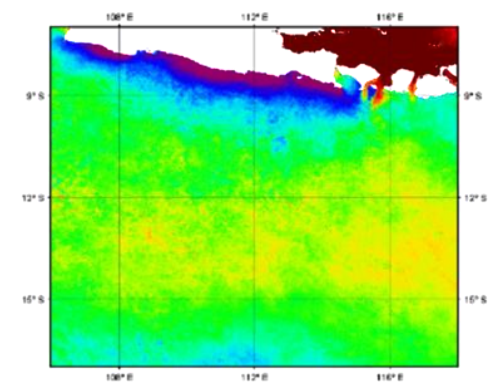

(c)

$24.00 \quad 25.50 \quad 27.00 \quad 28.50 \quad 30.00$

Gambar 5. Sebaran spasial suhu permukaan laut Musim Timur. (a) Tahun 2006, (b) Tahun 2007, (c) Tahun 2008, (d) Tahun 2009, (e) Tahun 2010.

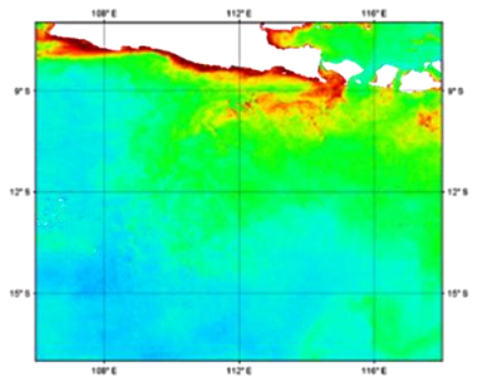

(a)

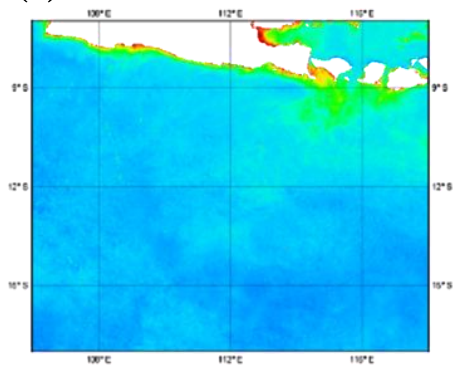

(d)

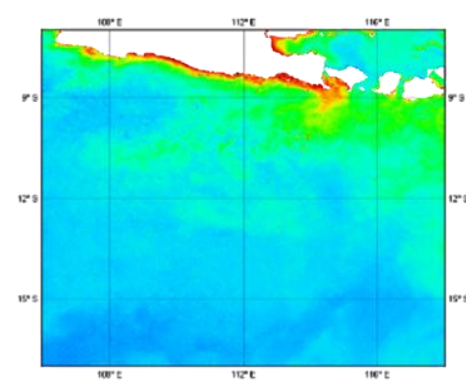

(b)

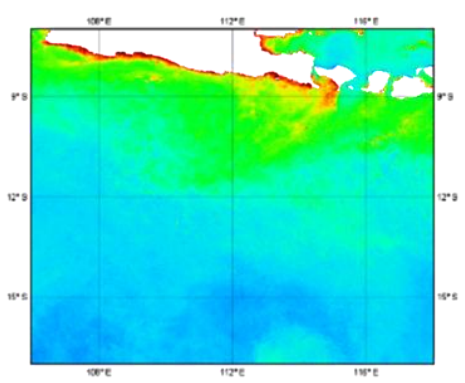

(c)

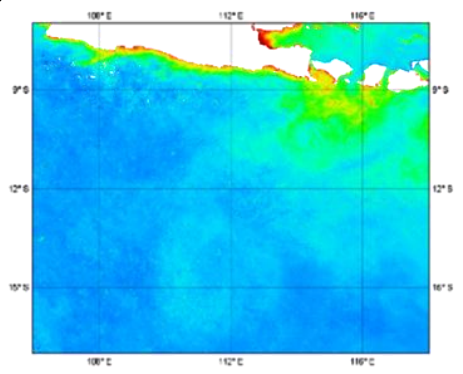

(e)

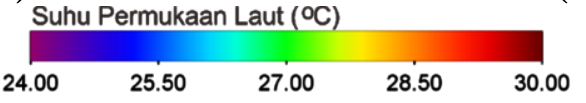

Gambar 6. Sebaran spasial klorofil-a bulan Juni 2006-2010. (a) Tahun 2006, (b) Tahun 2007, (c) Tahun 2008, (d) Tahun 2009, (e) Tahun 2010.

Bulan Agustus 2008 suhu permukaan laut berkisar antara $23-27^{\circ} \mathrm{C}$. Bulan Agustus 2009 nilai suhu permukaan laut berkisar antara $24-28^{\circ} \mathrm{C}$. Bulan Agustus 2010 nilai suhu permukaan laut berkisar antara $24-29,6^{\circ} \mathrm{C}$.
Gambar 5 menampilkan sebaran suhu permukaan laut pada musim timur (Juni, Juli, Agustus) tahun 2006-2010. Pada Musim Timur tahun 2006 suhu permukaan laut berkisar antara 24-28 ${ }^{\circ} \mathrm{C}$. Musim Timur tahun 2007 suhu 


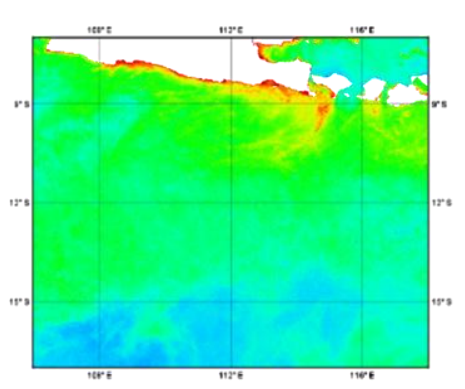

(a)

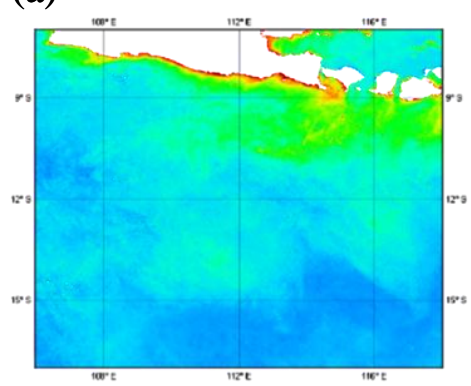

(d)

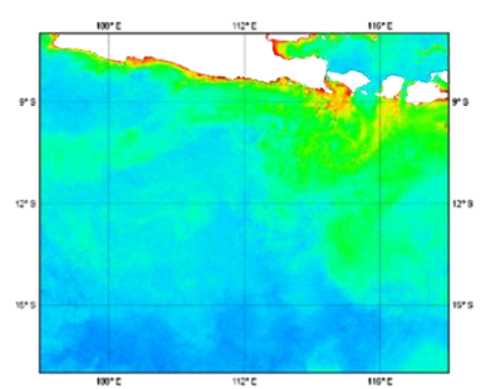

(b)

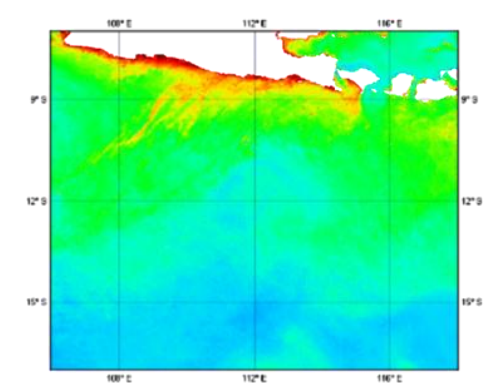

(c)

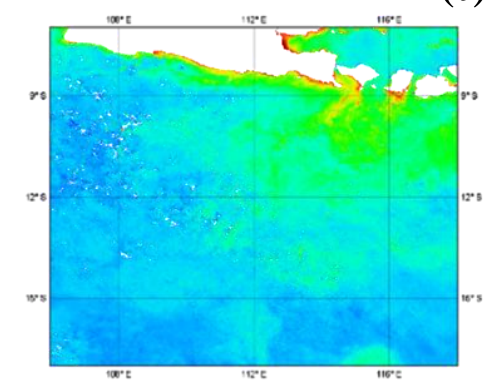

(e)

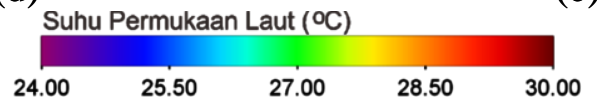

Gambar 7. Sebaran spasial klorofil-a bulan Juli 2006-2010. (a) Tahun 2006, (b) Tahun 2007, (c) Tahun 2008, (d) Tahun 2009, (e) Tahun 2010.

permukaan laut berkisar antara $25-28,6^{\circ} \mathrm{C}$. Musim Timur tahun 2008 suhu permukaan laut berkisar antara $23,7-27,5^{\circ} \mathrm{C}$. Musim Timur tahun 2009 suhu permukaan laut berkisar antara $25-29^{\circ} \mathrm{C}$. Musim Timur tahun 2010 sebaran suhu permukaan laut berkisar antara $25-30^{\circ} \mathrm{C}$.

\subsubsection{Sebaran Spasial Klorofil-a}

Gambar 6 menampilkan sebaran spasial klorofil-a pada bulan Juni tahun 2006-2010. Bulan Juni 2006 klorofil-a berkisar antara $0,05-10 \mathrm{mg} / \mathrm{m}^{3}$. Bulan Juni 2007 sebaran klorofil-a berkisar antara 0,04-8 $\mathrm{mg} / \mathrm{m}^{3}$. Bulan Juni 2008 sebaran klorofil-a berkisar antara 0,07-10 mg/m³. Bulan Juni 2009 sebaran klorofil-a berkisar antara $0,04-4 \mathrm{mg} / \mathrm{m}^{3}$. Bulan Juni 2010 sebaran klorofil-a berkisar antara 0,03-4 $\mathrm{mg} / \mathrm{m}^{3}$.

Gambar 7 menampilkan sebaran spasial klorofil-a pada bulan Juli tahun 2006-2010. Bulan Juli 2006 sebaran klorofil-a berkisar antara 0,05-7 $\mathrm{mg} / \mathrm{m}^{3}$. Bulan Juli 2007 sebaran klorofil-a berkisar antara 0,07-9 mg/m $\mathrm{m}^{3}$. Bulan Juli 2008 sebaran klorofil-a berkisar antara $0,08-10 \mathrm{mg} / \mathrm{m}^{3}$. Bulan Juli 2009 sebaran klorofil-a berkisar antara 0,05-6 $\mathrm{mg} / \mathrm{m}^{3}$. Bulan Juli 2010 kisaran nilai klorofil-a di perairan selatan Jawa hingga antara $0,03-5 \mathrm{mg} / \mathrm{m}^{3}$.

Gambar 8 menampilkan sebaran spasial klorofil-a pada bulan Agustus tahun 2006-2010 di perairan Selatan Jawa hingga Sumbawa. Bulan agustus 2006 klorofil-a berkisar antara 0,09-10 $\mathrm{mg} / \mathrm{m}^{3}$. Bulan Agustus 2007 sebaran klorofil-a berkisar antara 0,08-10 mg/m³. Bulan Agustus 2008 sebaran klorofil-a berkisar antara $0,05-10 \mathrm{mg} / \mathrm{m}^{3}$. Bulan Agustus 2009 sebaran klorofil-a berkisar antara $0,07-10 \mathrm{mg} / \mathrm{m}^{3}$. Bulan Agustus 2010 sebaran klorofil-a berkisar antara $0,04-4 \mathrm{mg} / \mathrm{m}^{3}$.

Sebaran spasial klorofil-a pada Musim Timur (Juni, Juli, Agustus) tahun 2006-2010 di perairan Selatan Jawa hingga Sumbawa ditampilkan pada Gambar 9. Pada Musim Timur tahun 2006 sebaran klorofil-a berkisar antara 0,09-10 mg/m ${ }^{3}$. Musim Timur tahun 2007 sebaran klorofil-a berkisar antara 0,09-10 mg/m³. Musim Timur tahun 2008 sebaran klorofil-a berkisar antara 0,09-10 mg/m ${ }^{3}$. Musim Timur tahun 2009 klorofil-a sekitar 0,07-0,4 $\mathrm{mg} / \mathrm{m}^{3}$. Musim Timur tahun 2010 sebaran klorofila berkisar $0,05-4 \mathrm{mg} / \mathrm{m}^{3}$.

\subsubsection{Hasil Tangkapan Tuna Mata Besar}

Data hasil tangkapan tuna mata besar yang diperoleh pada bulan Juni, Juli, Agustus tahun 2006-2010 ditampilkan pada Gambar 10. Hasil tangkapan pada bulan Juni tahun 2006-2010 mencapai 968 ekor dengan hasi tangkapan tertinggi berada di bulan Juni 2006 dan Juni 2007 sebesar 304 ekor dan hasil tangkapan terendah 


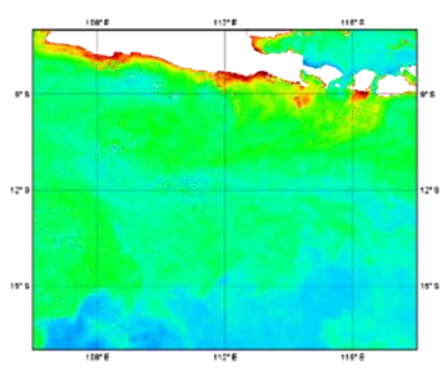

(a)

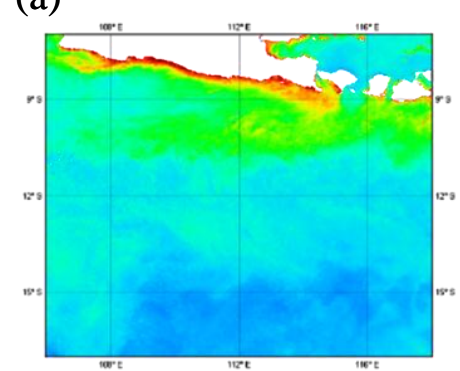

(d)

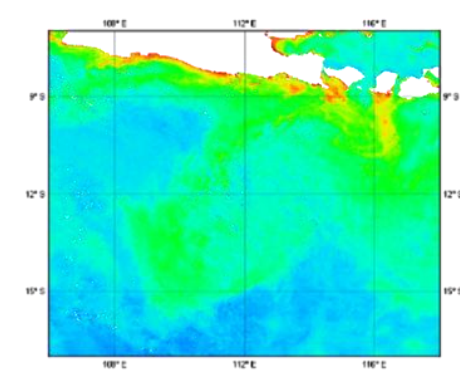

(b)

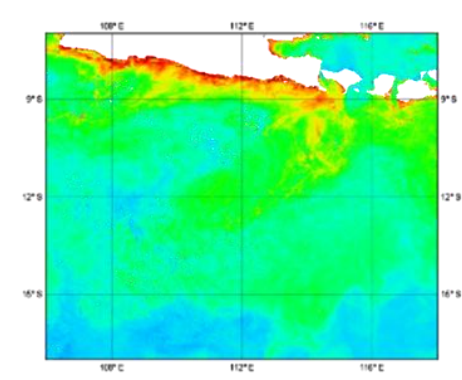

(c)

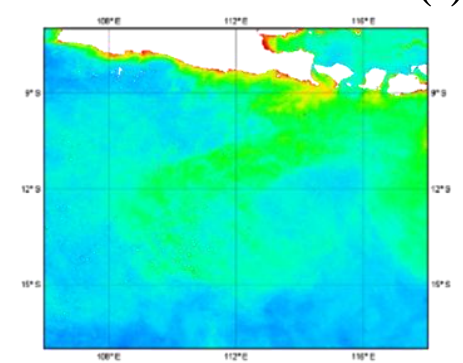

(e)

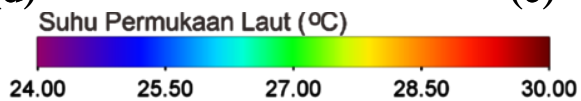

Gambar 8. Sebaran spasial klorofil-a bulan Agustus 2006-2010. (a) Tahun 2006, (b) Tahun 2007, (c) Tahun 2008, (d) Tahun 2009, (e) Tahun 2010.

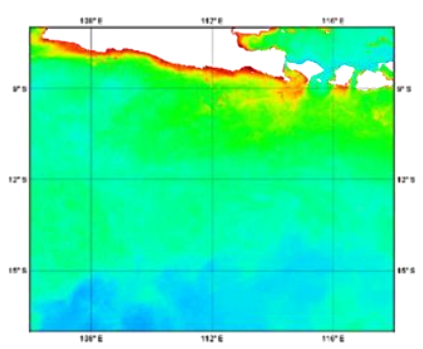

(a)

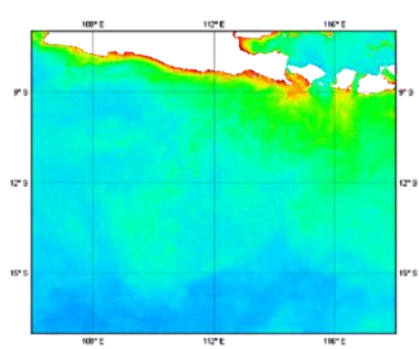

(b)

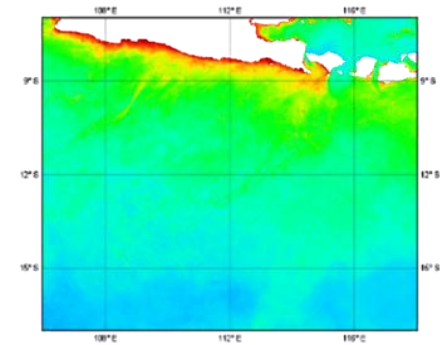

(c)

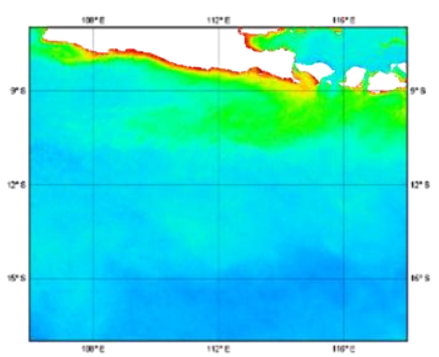

(d)

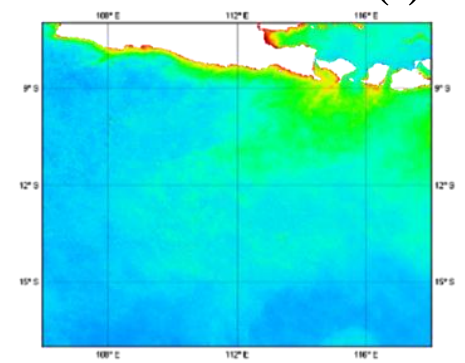

(e)

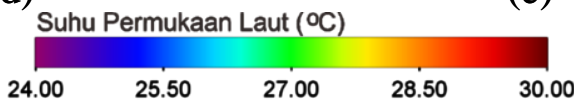

Gambar 9. Sebaran spasial klorofil-a Musim Timur tahun 2006-2010. (a) Tahun 2006, (b) Tahun 2007, (c) Tahun 2008, (d) Tahun 2009, (e) Tahun 2010.

berada di bulan Juni 2010 sebesar 63 ekor. Bulan Juli dari tahun 2006-2010 sebesar 1062 ekor dengan hasil tangkapan tertinggi pada bulan Juli 2009 dengan hasil tangkapan sebesar 495 ekor dan hasil tangkapan terendah berada pada bulan Juli 2010 sebesar 57 ekor. Bulan Agustus tahun 2006-2010 hasil tangkapan tuna mata besar mencapai 908 ekor dengan hasil tangkapan tertinggi berada di bulan Agustus tahun 2006 sebesar 319 ekor dan hasil tangkapan terendah berada di bulan Agustus tahun 2007 sebesar 97 ekor.

Hasil tangkapan tuna mata besar dari tahun 2006-2010 mengalami fluktuasi setiap tahunnya dengan jumlah keseluruhan hasil tangkapan tuna 
mata besar dari tahun 2006-2010 sebesar 2915 ekor. Dari keseluruhan hasil tangkapan tahun 2006-2010 jumlah tangkapan tertinggi terjadi pada tahun 2009 dengan jumlah tangkapan sebesar 1009 ekor dan jumlah tangkapan terendah terjadi pada tahun 2010 dengan jumlah tangkapan sebesar 198 ekor. Hasil tangkapan tuna mata besar pada Musim Timur tahun 2006-2010 ditampilkan pada Gambar 11.

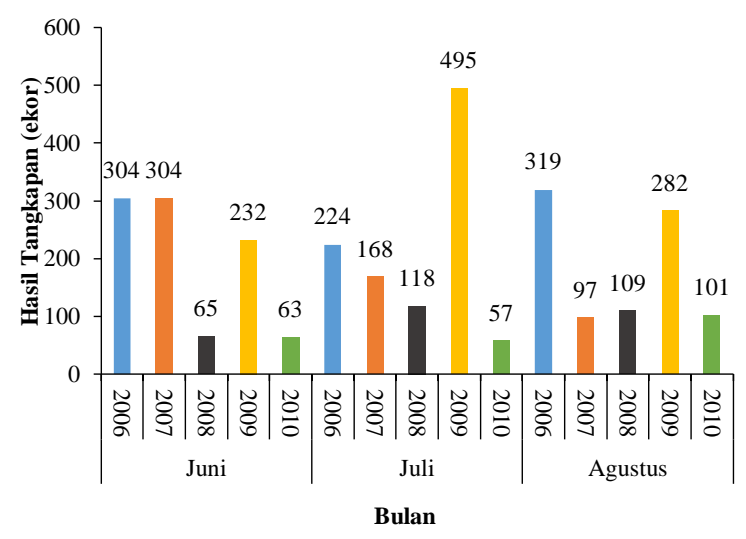

Gambar 10. Grafik hasil tangkapan tuna mata besar Bulan Juni, Juli, Agustus tahun 2006-2010.

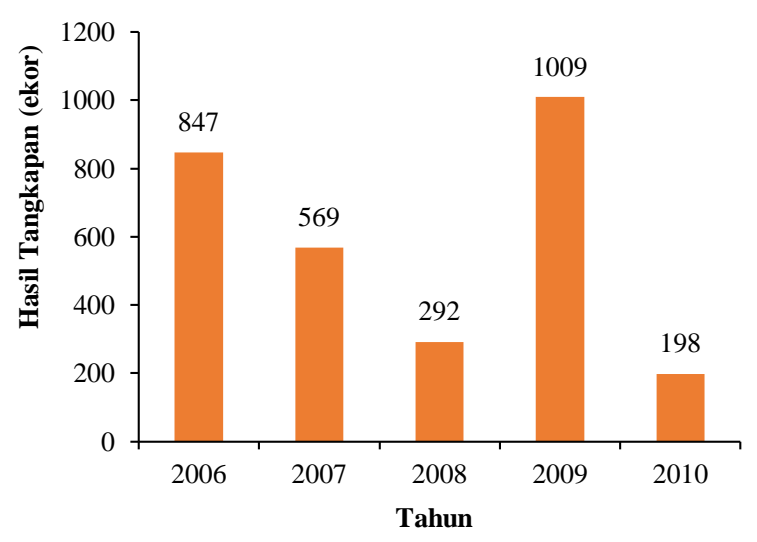

Gambar 11. Grafik hasil tangkapan tuna mata besar Musim Timur tahun 2006-2010.

3.1.4. Hubungan Suhu Permukaan Laut dengan Jumlah Tangkapan Tuna Mata Besar

Grafik jumlah tangkapan tuna mata besar dengan suhu permukaan laut ditampilkan pada Gambar 12. Jumlah tangkapan tuna mata besar untuk kelompok null catch, positif catch, dan high catch berada pada suhu $24-29,8^{\circ} \mathrm{C}$. Jumlah tangkapan pada kelompok null catch berada di suhu 24,1 $29,3^{\circ} \mathrm{C}$. Jumlah tangkapan untuk kelompok positif catch berada di suhu $24-29,8^{\circ} \mathrm{C}$. Selanjutnya untuk kelompok high catch, jumlah tangkapan berada di suhu $24-29^{\circ} \mathrm{C}$.

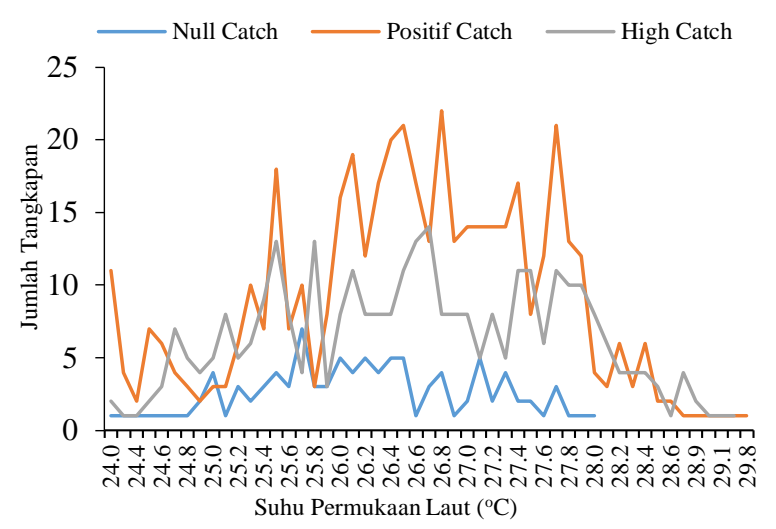

Gambar 12. Grafik jumlah tangkapan dengan suhu permukaan laut Musim Timur (Juni, Juli, Agustus) tahun 2006-2010. (a)

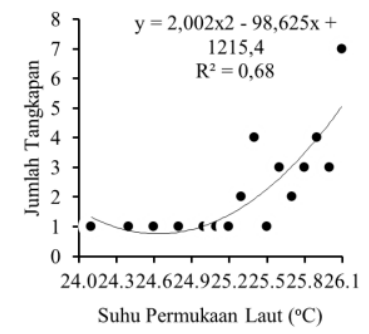

(b)

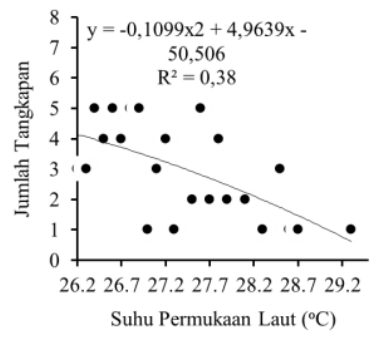

Gambar 13. Hubungan jumlah tangkapan tuna mata besar dengan suhu permukaan laut kelompok null catch. (a) Suhu permukaan laut kurang dari $26,1^{\circ} \mathrm{C}$ dan (b) Suhu permukaan laut lebih dari $26,2^{\circ} \mathrm{C}$.

Berdasarkan analisis yang dilakukan terhadap kelompok null catch (Gambar 13), ketika suhu kurang dari $26,1^{\circ} \mathrm{C}$ diperoleh nilai koefisien determinansi sebesar 0,68. Ketika suhu lebih dari $26,2^{\circ} \mathrm{C}$ diperoleh nilai koefisien determinansi sebesar 0,38. Nilai korelasi ketika suhu kurang dari $26,1^{\circ} \mathrm{C}$ sebesar 0,72 dan ketika suhu lebih dari $26,2^{\circ} \mathrm{C}$ sebesar $-0,62$.

Hasil perhitungan hubungan jumlah tangkapan dengan suhu permukaan laut yang dilakukan pada kelompok positif catch ditampilkan pada Gambar 14. Ketika kondisi suhu kurang dari $26,8^{\circ} \mathrm{C}$ diperoleh nilai koefisien determinasi sebesar 0,65. Pada kondisi suhu lebih dari $26,9^{\circ} \mathrm{C}$ diperoleh nilai koefisien determinansi sebesar 0,71. Ketika suhu kurang dari $26,8^{\circ} \mathrm{C}$ nilai korelasi yang dihasilkan sebesar 0,75 dan ketika suhu lebih dari $26,9^{\circ} \mathrm{C}$ nilai korelasi yang dihasilkan sebesar $-0,83$. 
(a)

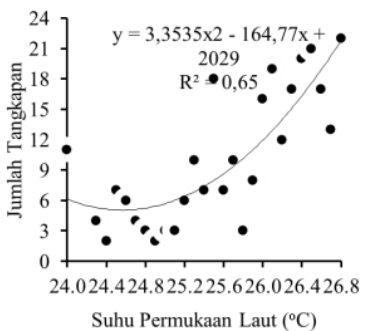

(b)

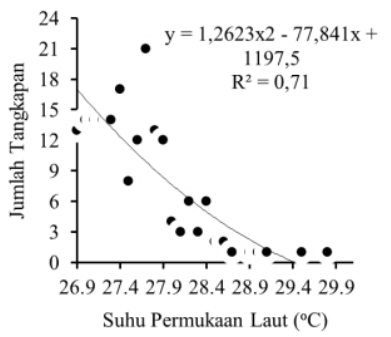

Gambar 14. Hubungan jumlah tangkapan tuna mata besar dengan suhu permukaan laut kelompok positif catch. (a) Suhu permukaan laut kurang dari $26,8^{\circ} \mathrm{C}$ dan (b) Suhu permukaan laut lebih dari $26,9^{\circ} \mathrm{C}$.

Hasil perhitungan jumlah tangkapan dengan suhu permukaan laut kelompok high catch ditunjukan pada Gambar 15. Ketika kondisi suhu kurang dari $26,6^{\circ} \mathrm{C}$ diperoleh nilai koefisien determinasi sebesar 0,59. Ketika kondisi suhu lebih dari $26,7^{\circ} \mathrm{C}$ diperoleh nilai koefisien determinansi sebesar 0,68 . Nilai korelasi ketika suhu kurang dari $26,6^{\circ} \mathrm{C}$ sebesar 0,76 dan nilai korelasi ketika suhu lebih dari $26,7^{\circ} \mathrm{C}$ sebesar $-0,73$.

(a)
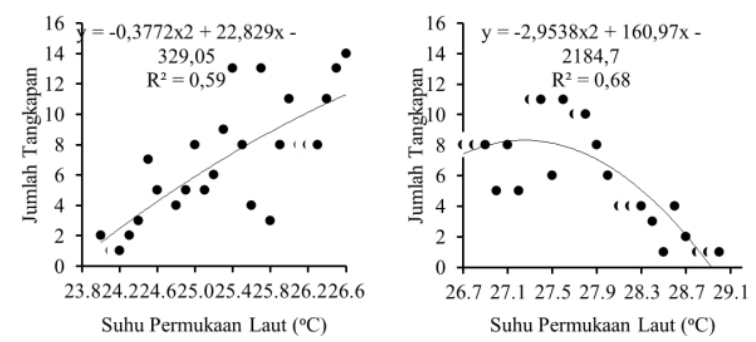

Gambar 15. Hubungan jumlah tangkapan tuna mata besar dengan suhu permukaan laut kelompok high catch. (a) Suhu permukaan laut kurang dari $26,6^{\circ} \mathrm{C}$ dan (b) Suhu permukaan laut lebih dari $26,7^{\circ} \mathrm{C}$.

3.1.3 Hubungan Klorofil-a dengan Jumlah Tangkapan Tuna Mata Besar

Jumlah tangkapan tuna mata besar untuk kelompok null catch, positif catch, high catch memiliki pola yang fluktuatif pada sebaran klorofil-a 0,01-0,82 mg/m $\mathrm{m}^{3}$. Jumlah tangkapan pada kelompok null catch berada di sebaran klorofil-a $0,02-0,53 \mathrm{mg} / \mathrm{m}^{3}$. Jumlah tangkapan kelompok positif catch berada di sebaran klorofil-a 0,01-0,82 $\mathrm{mg} / \mathrm{m}^{3}$. Selanjutnya untuk kelompok high catch, jumlah tangkapan berada pada sebaran klorofil-a
0,01-0,55 $\mathrm{mg} / \mathrm{m}^{3}$. Grafik jumlah tangkapan tuna mata besar dengan klorofil-a pada Musim Timur ditampilkan pada Gambar 16.

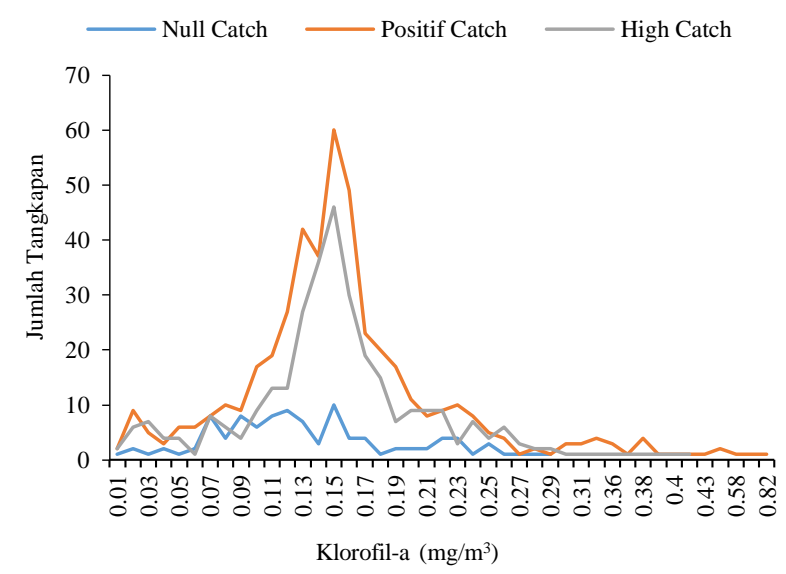

Gambar 16. Grafik jumlah tangkapan dengan sebaran klorofil-a musim Timur (Juni, Juli, Agustus) tahun 20062010.

Gambar 17 menunjukan hasil analisis klorofil-a dengan jumlah tangkapan kelompok null catch. Ketika klorofil-a kurang dari $0,18 \mathrm{mg} / \mathrm{m}^{3}$ diperoleh nilai koefisien determinansi sebesar 0,57. Ketika kondisi klorofil-a lebih dari $0,19 \mathrm{mg} / \mathrm{m}^{3}$ diperoleh nilai koefisien determinansi sebesar 0,31 . Nilai korelasi ketika kondisi klorofil-a kurang dari 0,18 $\mathrm{mg} / \mathrm{m}^{3}$ sebesar 0,75 dan ketika klorofil-a lebih dari $0,19 \mathrm{mg} / \mathrm{m}^{3}$ sebesar $-0,56$.

Hasil perhitungan klorofil-a dengan jumlah tangkapan kelompok positif catch ditunjukan pada Gambar 18. Berdasarkan perhitungan yang dilakukan, ketika sebaran klorofil-a kurang dari $0,15 \mathrm{mg} / \mathrm{m}^{3}$ diperoleh nilai koefisien determinansi sebesar 0,94 . Ketika kondisi klorofil-a lebih dari $0,16 \mathrm{mg} / \mathrm{m}^{3}$ diperoleh nilai koefisien determinansi sebesar 0,56 . Nilai korelasi ketika klorofil-a kurang dari $0,15 \mathrm{mg} / \mathrm{m}^{3}$ sebesar 0,86 dan ketika klorofil-a (a)

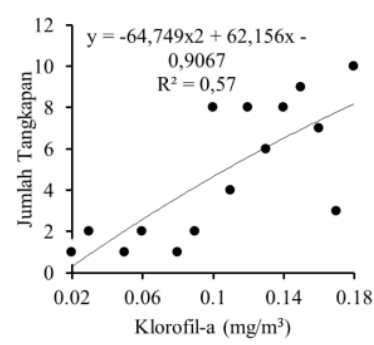

(b)

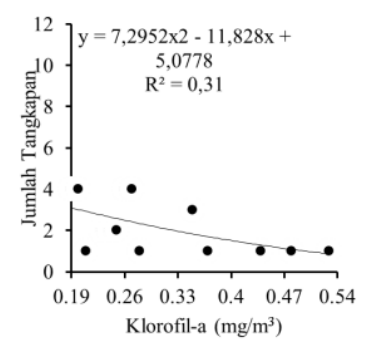

Gambar 17. Hubungan jumlah tangkapan tuna mata besar dengan klorofil-a kelompok null catch. (a) Klorofila kurang dari $0,18 \mathrm{mg} / \mathrm{m}^{3}$ dan (b) Klorofil-a lebih dari $0,19 \mathrm{mg} / \mathrm{m}^{3}$. 
(a)

(b)
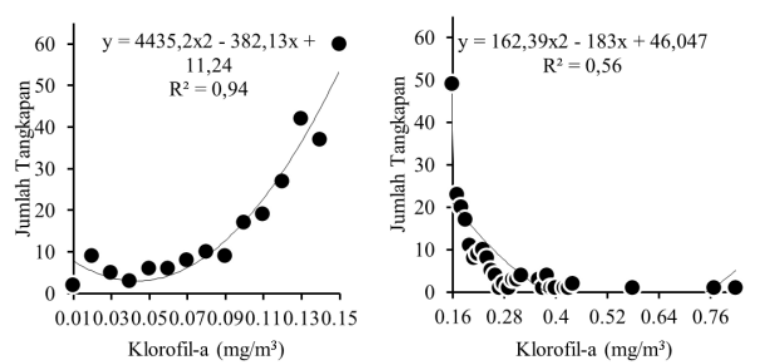

Gambar 18. Hubungan klorofil-a dengan jumlah tangkapan tuna mata besar kategori positif catch. (a) Klorofil-a kurang dari $0,15 \mathrm{mg} / \mathrm{m}^{3}$ dan (b) Klorofil-a lebih dari $0,16 \mathrm{mg} / \mathrm{m}^{3}$.

lebih dari $0,16 \mathrm{mg} / \mathrm{m}^{3}$ sebesar $-0,51$.

Gambar 19 menunjukan hasil perhitungan klorofil-a dengan jumlah tangkapan tuna mata besar kategori high catch. Ketika klorofil-a kurang dari $0,15 \mathrm{mg} / \mathrm{m}^{3}$ diperoleh nilai koefisien determinansi sebesar 0,92. Ketika kondisi klorofil-a lebih dari $0,16 \mathrm{mg} / \mathrm{m}^{3}$ diperoleh nilai koefisien determinansi sebesar 0,75. Nilai korelasi ketika kondisi klorofil-a kurang dari $0,15 \mathrm{mg} / \mathrm{m}^{3}$ sebesar 0,79 dan ketika kondisi klorofil-a lebih dari 0,16 $\mathrm{mg} / \mathrm{m}^{3}$ sebesar $-0,69$. (a)

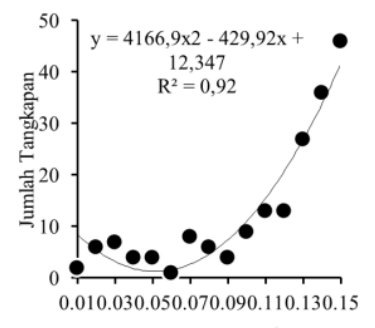

Klorofil-a $\left(\mathrm{mg} / \mathrm{m}^{3}\right)$ (b)

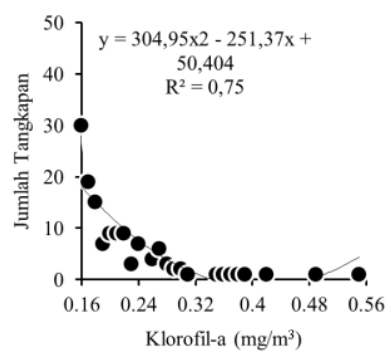

Gambar 19. Hubungan klorofil-a dengan jumlah tangkapan tuna mata besar kelompok high catch. (a) Klorofil-a kurang dari $0,15 \mathrm{mg} / \mathrm{m}^{3}$ dan (b) Klorofil-a lebih dari $0,16 \mathrm{mg} / \mathrm{m}^{3}$.

\subsection{Pembahasan}

Berdasarkan tampilan citra satelit modis yang digunakan dalam penelitian ini memperlihatkan sedikit tutupan awan yang mempengaruhi nilai suhu permukaan laut dan klorofil-a, hanya saja warna putih yang ada di citra menunjukkan keberadaan daratan. Pada Musim Timur bulan Juni-Agustus tahun 2006-2010 suhu permukaan laut di perairan Selatan Jawa-Bali terlihat bervariasi berkisar antara $24-30^{\circ} \mathrm{C}$. Pola penyebaran suhu permukaan laut di selatan Jawa dan Bali sangat erat kaitannya dengan pola angin yang bertiup. Kuatnya angin musim timur yang bertiup ini berpengaruh terhadap pergerakan arus permukaan di perairan selatan Jawa dan Bali. Pergerakan arus yang terjadi di selatan Jawa dan Bali yaitu pergerakan arus khatulistiwa selatan (AKS) yang mengalir ke arah barat (Kessler and Cravatte, 2013).

Selain pengaruh angin dan arus, adanya fenomena ENSO (El Ninõ Southern Oscillation) dan IOD (Indian Ocean Dipole) mempengaruhi sebaran suhu permukaan laut di selatan Jawa dan Bali (Assyakur et al., 2014). Fenomena IOD fase positif terjadi bersamaan dengan fenomena El Ninõ pada Musim Timur tahun 2006. Fenomena IOD fase negatif ini terjadi secara bersamaan dengan fenomena La Nina pada Musim Timur tahun 2010 (As-syakur, 2015). Menurut Saji (1999) ketika fenomena IOD positif terjadi menyebabkan suhu permukaan laut di Samudera Hindia bagian barat menjadi lebih hangat dan suhu permukaan laut di Samudera Hindia bagian timur menjadi lebih dingin, begitu sebaliknya ketika fenomena IOD negative terjadi.

Sebaran klorofil-a di laut sangat bervariasi dan bergantung pada intensitas cahaya matahari, arus yang terjadi di perairan, dan suhu permukaan laut (Sihombing dkk., 2012). Pada tampilan citra sebaran klorofil-a terlihat nilai klorofil-a tinggi berada di perairan pesisir selatan Jawa dan Bali. Tingginya kandungan klorofil-a di perairan pesisir disebabkan oleh adanya asupan nutrien yang berasal dari daratan yang terbawa oleh aliran sungai dan bermuara ke laut. Selain itu tingginya kandungan klorofil-a di perairan pesisir selatan Jawa dan Bali juga disebabkan oleh fenomena upwelling. Seperti pada Musim Timur tahun 2006, sebaran klorofil-a di perairan selatan Jawa dan Bali bernilai tinggi, sedangkan suhu permukaan laut bernilai rendah. Ini kemungkinan dikarenakan adanya fenomena IOD fase positif yang bersamaan dengan fenomena El Ninõ. Menurut Kemili dan Putri (2012) fenomena El Ninõ dan IOD positif yang terjadi bersamaan di perairan Indonesia umumnya menyebabkan durasi upwelling yang lebih lama dan intensitas upwelling meningkat sehingga menghasilkan produktivitas yang lebih tinggi. Disisi lain, Syamsuddin et al. (2013) juga mengungkapkan bahwa kejadian El Nino memiliki pengaruh yang cukup kuat terhadap fluktuasi hasil tangkapan ikan tuna mata besar di perairan selatan Jawa dan Bali. 
Berdasarkan hasil analisis dari ketiga kelompok, bahwa suhu permukaan laut dan klorofil-a berhubungan dengan jumlah tangkapan tuna mata besar selatan Jawa dan Bali. Kelompok positif dan high catch merupakan kelompok yang paling signifikan digunakan untuk kegiatan penangkapan. Terlihat dari hasil analisis korelasi kelompok positif dan high catch memiliki nilai korelasi yang tinggi dibandingkan kelompok null catch. Tingginya nilai korelasi pada kelompok positif catch dan high catch ini, mengindikasikan terjadi hubungan yang sangat kuat antara suhu permukaan laut dan klorofil-a dengan jumlah tangkapan tuna mata besar. Dimana suhu optimal untuk tangkapan pada kelompok positif catch yaitu $26,7^{\circ} \mathrm{C}-27^{\circ} \mathrm{C}$ dan kelompok high catch yaitu $26,4^{\circ} \mathrm{C}-$ $26,8^{\circ} \mathrm{C}$. Sedangkan jumlah tangkapan tuna mata besar lebih dominan berada pada sebaran klorofila rendah yaitu $0,09-0,2 \mathrm{mg} / \mathrm{m}^{3}$.

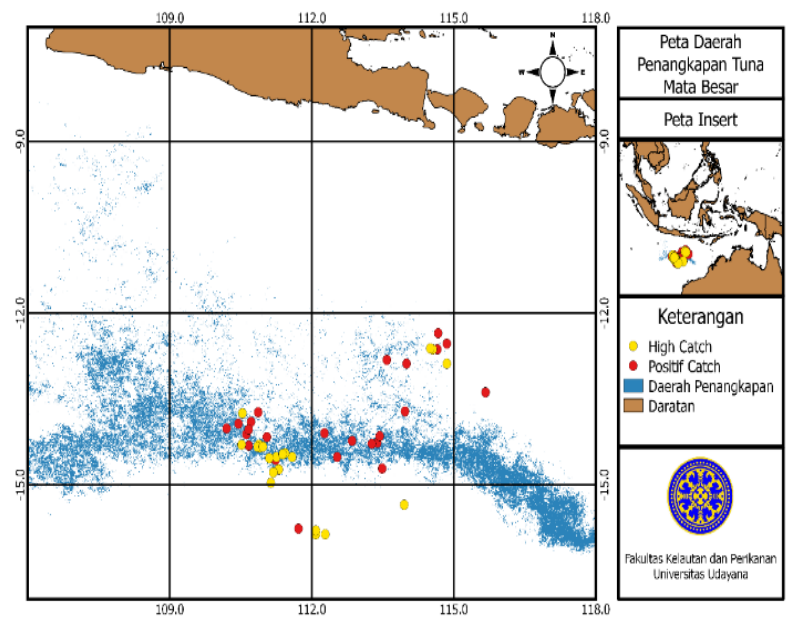

Gambar 20. Peta daerah penangkapan tuna mata besar di selatan Jawa dan Bali

Menurut Howell et al. (2010), ketika berada di dekat dengan permukaan perairan tuna mata besar menghabiskan waktu berada di sekitar suhu permukaan laut $28^{\circ} \mathrm{C}$. Tuna mata besar lebih memilih untuk tinggal di perairan dengan konsentrasi nutrisi rendah, dimana konsentrasi nutrisi yang rendah akan menurunkan konsentrasi klorofil-a dan kondisi ini berdampak pada laju pertemuan makanan. Tuna mata besar lebih memilih bergerak menuju perairan dengan suhu lebih rendah untuk mencegah panas berlebih (Brill et al., 2005). Hal ini terlihat dari peta daerah penangkapan tuna mata besar di selatan Jawa dan Bali (Gambar 20).

Berdasarkan daerah penangkapan tuna mata besar, seperti yang ditunjukkan pada Gambar 20, dapat dijelaskan bahwa sebagian besar penangkapan tuna mata besar berada di $12^{\circ} \mathrm{LS}$ $15^{\circ} \mathrm{LS}$ dan $106^{\circ} \mathrm{BT}-118^{\circ} \mathrm{BT}$. Ini sesuai dengan pernyataan Wibawa (2011) bahwa ketika memasuki Musim Timur (Juni, Juli, Agustus) daerah potensial penangkapan tuna mata besar cenderung berada dibawah $15^{\circ}$ LS.

Dimana pada daerah ini konsentrasi klorofil-a lebih rendah dibandingkan dengan daerah pesisir. Tuna mata besar lebih dominan berada di dekat lapisan permukaan hingga di atas lapisan termoklin dengan kedalaman mencapai 100 meter pada waktu malam hari dibandingkan dengan waktu siang hari. Pada siang hari tuna mata besar lebih dominan berenang hingga kedalaman lebih dari 500 meter (Howell et al., 2010). Dimana ada kondisi perairan dengan klorofil-a dan suhu permukaan laut maksimum yang disukai oleh tuna mata besar untuk tinggal dan mencari mangsa.

\section{Simpulan}

Berdasarkan hasil penelitian dan analisis data, adapun kesimpulan yang diperoleh yaitu pada kelompok null catch hubungan suhu permukaan laut dengan jumlah tangkapan tuna mata besar memiliki hubungan yang kuat. Hubungan yang kuat juga terlihat antara suhu permukaan laut dengan jumlah tangkapan tuna mata besar pada kelompok positif dan high catch. Hubungan yang kuat terlihat antara klorofil-a dengan jumlah tangkapan tuna mata besar pada kelompok null catch, kelompok positif dan high catch dimana hubungan yang kuat juga terlihat antara klorofil-a dengan jumlah tangkapan tuna mata besar. Daerah penangkapan tuna mata besar di perairan Selatan Jawa dan Bali berada pada posisi $12^{\circ} \mathrm{LS}-15^{\circ} \mathrm{LS}$ dan $106^{\circ} \mathrm{BT}-118^{\circ} \mathrm{BT}$.

\section{Ucapan terimakasih}

Penulis mengucapkan terima kasih kepada PT. Peerikanan Nusantara, Benoa, Bali untuk data perikanan yang diberikan. Kepada National Aeronautics and Space Administration (NASA) atas citra satelit Aqua MODIS. Terimakasih juga diucapkan kepada keluarga besar Fakultas Kelautan dan Perikanan Universitas Udayana serta teman-teman ilmu kelautan angkatan satu atas segala bantuan yang telah diberikan, serta seluruh pihak yang telah memberikan saran dan bimbingan dalam penelitian ini. 


\section{Daftar Pustaka}

Andrade, H. A., \& Garcia, C. A. (1999). Skipjack tuna fishery in relation to sea surface temperature off the southern Brazilian coast. Fisheries oceanography, 8(4), 245-254.

Arrizabalaga, H., Dufour, F., Kell, L., Merino, G., Ibaibarriaga, L., Chust, G., Irigoien X., Santiago J., Murua H., Fraile I., Chifflet M., Goikoetxea N., Sagarminaga Y., Olivier, A., Bopp L., Herrera M., Fromentin J. M., \& Bonhomeau S. (2015). Global habitat preferences of commercially valuable tuna. Deep Sea Research Part II: Topical Studies in Oceanography, 113, 102-112.

As-syakur, A. R. (2015). Spatio-Temporal Variations of Rainfall and SST Anomaly over Indonesia during ENSO Modoki Event in 2010. Journal of Marine and Aquatic Sciences, 1(1), 23-29.

As-syakur, A., Adnyana, I. W. S., Mahendra, M. S., Arthana, I. W., Merit, I. N., Kasa, I. W., Ekayanti, N. W., Nuarsa, I. W., \& Sunarta, I. N. (2014). Observation of spatial patterns on the rainfall response to ENSO and IOD over Indonesia using TRMM Multisatellite Precipitation Analysis (TMPA). International Journal of Climatology, 34(15), 3825-3839.

Bahtiar, A., Barata, A., \& Novianto, D. (2013). Fishing tactics for bigeye tuna (Thunnus obesus) in Indian Ocean based on hook timer and minilogger data. Jurnal penelitian perikanan Indonesia, 19(1), 47-53

Barata, R. B. Y., Setyono, H., \& Harsono, G. (2014). Dinamika upwelling dan downwelling berdasarkan variabilitas suhu permukaan laut dan klorofil-a di perairan Selatan Jawa. Jurnal Oseanografi, 3(1), 57-66.

Bender, M. G., Machado, G. R., de Azevedo Silva, P. J., Floeter, S. R., Monteiro-Netto, C., Luiz, O. J., \& Ferreira, C. E. (2014). Local ecological knowledge and scientific data reveal overexploitation by multigear artisanal fisheries in the Southwestern Atlantic. PLoS One, 9(10), e110332.

Brill, R. W., Bigelow, K. A., Musyl, M. K., Fritsches, K. A., \& Warrant, E. J. (2005). Bigeye tuna (Thunnus obesus) behavior and physiology and their relevance to stock assessments and fishery biology. Collective volume of scientific papers-ICCAT, 57(2), 142-161.

Ekayana, I. M., Karang, I. W. G. A., As-syakur, A. R., Jatmiko, I., \& Novianto, D. (2017). Hubungan Hasil Tangkapan Ikan Tuna Selama Februari-Maret 2016 dengan Konsentrasi Klorofil-a dan SPL dari Data Penginderaan Jauh Di Perairan Selatan Jawa - Bali. Journal of Marine and Aquatic Sciences, 3(1), 19-29.

Howell, E. A., Hawn, D. R., \& Polovina, J. J. (2010). Spatiotemporal variability in Bigeye tuna (Thunnus obesus) dive behaviour in the Central North Pacific Ocean. Progress in oceanography, 86(1), 81-93.

ISSF. (2015). ISSF Tuna Stock Status Update, 2015: Status of the world fisheries for tuna. ISSF Technical Report 2015-
03A. Washington, D.C., USA: International Seafood Sustainability Foundation.

IOTC. (2014). Status of the Indian Ocean bigeye tuna (BET: Thunnus obesus) resource. [online] The Indian Ocean Tuna Commission (IOTC). (http://www.iotc.org/sites/ default/files/documents/2014/12/IOTC-2014-SC17ES02 E_-_Bigeye_tuna.pdf), [diakses: 1 Maret 2016].

Kaplan, D. M., Chassot, E., Amandé, J. M., Dueri, S., Demarcq, H., Dagorn, L., \& Fonteneau, A. (2014). Spatial management of Indian Ocean tropical tuna fisheries: potential and perspectives. ICES Journal of Marine Science: Journal du Conseil, 71(7), 1728-1749.

Kemili, P., \& Putri, M. R. (2012). Pengaruh durasi dan intensitas upwelling berdasarkan anomali suhu permukaan laut terhadap variabilitas produktivitas primer di perairan Indonesia. Jurnal Ilmu dan Teknologi Kelautan Tropis, 4(1), 66-79.

Kessler, W. S., \& Cravatte, S. (2013). ENSO and shortterm variability of the South Equatorial Current entering the Coral Sea. Journal of Physical Oceanography, 43(5), 956-969.

KKP. (2015). Keputusan Menteri Kelautan dan Perikanan Nomor 107/KEPMEN-KP/2015 tentang Rencana Pengelolaan Perikanan Tuna, Cakalang dan Tongkol. Jakarta-Indonesia: Kementerian Kelautan dan Perikanan Republik Indonesia.

Lasabuda, R. (2013). Pembangunan Wilayah Pesisir dan Lautan dalam Perspektif Negara Kepulauan Republik Indonesia. Jurnal Ilmiah Platax, 1(2), 92-101.

Lumban-Gaol, J., Leben, R. R., Vignudelli, S., Mahapatra, K., Okada, Y., Nababan, B., Mei-Ling, M., Amri, K., Arhatin, R. E., \& Syahdan, M. (2015). Variability of satellite-derived sea surface height anomaly, and its relationship with Bigeye tuna (Thunnus obesus) catch in the Eastern Indian Ocean. European Journal of Remote Sensing, 48, 465-477.

Putra, E., Lumban-Gaol, J., \& Siregar, V. P. (2012). Hubungan konsentrasi klorofil-a dan suhu permukaan laut dengan hasil tangkapan ikan pelagis utama di perairan Laut Jawa dari citra satelit MODIS. Jurnal teknologi perikanan dan kelautan, 3(1), 1-10.

Saji, N. H., Goswami, B. N., Vinayachandran, P. N., \& Yamagata, T. (1999). A dipole mode in the tropical Indian Ocean. Nature, 401(6751), 360-363.

Semedi, B., \& Hadiyanto, A. L. (2013). Forecasting the Fishing Ground of Small Pelagic Fishes in Makassar Strait Using Moderate Resolution Image Spectroradiometer Satellite Images. Journal of Applied Environmental and Biological Sciences, 3(2), 29-34.

Semedi, B., \& Safitri, N. M. (2014). Estimasi Distribusi Klorofil-a di Perairan Selat Madura Menggunakan Data Citra Satelit Modis dan Pengukuran In Situ Pada Musim Timur. Research Journal of Life Science, 1(2), 117-126. 
Setiawati, M. D., Sambah, A. B., Miura, F., Tanaka, T., \& As-syakur, A. R. (2015). Characterization of bigeye tuna habitat in the Southern Waters off Java-Bali using remote sensing data. Advances in Space Research, 55(2), 732-746.

Sihombing, R. F., Aryawati, R., \& Hartoni. (2012). Kandungan klorofil-a fitoplankton di sekitar perairan Desa Sungsang kabupaten Banyuasin provinsi Sumatera Selatan. Maspari Journal, 5(1), 34-39.

Sunoko, R., \& Huang, H. W. (2014). Indonesia tuna fisheries development and future strategy. Marine Policy, 43, 174-183.

Swastana, I. G. A., As-syakur, A. R., \& Novianto, D. (2016). Karakteristik Ikan Tuna sirip biru selatan (Thunnus maccoyii) Hasil Tangkapan Kapal Rawai Tuna yang didaratkan di Pelabuhan Benoa. Journal of Marine and Aquatic Sciences, 2(2), 78-83.

Syamsuddin, M. L., Saitoh, S. I., Hirawake, T., Syamsudin, F., \& Zainuddin, M. (2016). Interannual variation of bigeye tuna (Thunnus obesus) hotspots in the eastern Indian Ocean off Java. International Journal of Remote Sensing, 37(9), 2087-2100.

Syamsuddin, M. L., Saitoh, S. I., Hirawake, T., Bachri, S., \& Harto, A. B. (2013). Effects of El Niño-Southern Oscillation events on catches of Bigeye Tuna (Thunnus obesus) in the eastern Indian Ocean off Java. Fishery Bulletin, 111(2), 175-188.

Tamarol, J., \& Wuaten, J. F. (2013). Daerah penangkapan ikan tuna (Thunnus sp.) di Sangihe, Sulawesi Utara. Jurnal Perikanan dan Kelautan Tropis, 9(2), 54-59.

Wibawa, T.A. (2011). Pemanfaatan data satelit oseanografi untuk prediksi daerah potensial penangkapan tuna mata besar (Thunnus obesus) di Samudra Hindia selatan Jawa-Bali. Jurnal Segara, 7(1), 29-41.

Zainuddin, M., Saitoh, K., \& Saitoh, S-I. (2008). Albacore (Thunnus alalunga) fishing ground in relation to oceanographic condition in the Western North Pasific Ocean using remotely sensed satellite data. Fisheries Oceanography, 17(2), 61-73.

(C) 2017 by the authors; licensee Udayana University, Indonesia. This article is an open access article distributed under the terms and conditions of the Creative Commons Attribution license (http://creativecommons.org/licenses/by/3.0/). 